\title{
The Returns to Computer Use Revisited, Again
}

\author{
by Benoit DOSTIE, Rajshri JAYARAMAN \\ and Mathieu TRÉPANIER
}

Cahier de recherche $\mathrm{n}^{0}$ IEA-06-03

APRIL 2006

ISSN : 0825-8643

\footnotetext{
Copyright (C) 2006. Benoit Dostie, Institut d'économie appliquée et Georges Dionne, Chaire de recherche du Canada en gestion des risques.

Tous droits réservés pour tous pays. Toute traduction ou toute reproduction sous quelque forme que ce soit est interdite.

Les textes publiés dans la série des Cahiers de recherche HEC n'engagent que la responsabilité de leurs auteurs.

La publication de ce Cahier de recherche a été rendue possible grâce à des subventions d'aide à la publication et à la diffusion de la recherche provenant des fonds de HEC Montréal.

Direction de la recherche, HEC Montréal, 3000, chemin de la Côte-Sainte-Catherine, Montréal (Québec) Canada H3T 2 A7.
} 


\title{
The Returns to Computer Use Revisited, Again*
}

\author{
Benoit Dostie ${ }^{\dagger}$ Rajshri Jayaraman ${ }^{\ddagger}$ and Mathieu Trépanier ${ }^{\S}$
}

April 6th, 2006

\begin{abstract}
Using North American data, we revisit the question first broached by Krueger (1993) and re-examined by DiNardo and Pischke (1997) of whether there exists a real wage differential associated with computer use. Employing a mixed effects model to correct for both worker and workplace unobserved heterogeneity using matched employer-employee panel data, we find that computer users enjoy an almost 4 per cent wage premium over non-users. Failure to correct for the worker selection effect leads to a more than twofold overestimate of this premium, as does failure to correct for workplace unobserved heterogeneity.

JEL classification: J30, J31, O30 ; KEY WORDS: Wage determination; Computers; Mixed models; Linked employer-employee data

*We thank Larry Blume, Richard Chaykovsky, Rob Clark, Nicole Fortin, Avi Goldfard, David Green, Paul Lanoie, Pierre-Thomas Léger, Thomas Lemieux, Asaf Razin, Paul Ruud, Klaus Schmidt, Michael Smart, Pierre-Yves Steunou and participants in the 2004 CEA and SCSE Conferences for valuable comments. We greatfully acknowledge financial support from the Social Sciences and Humanities Research Council of Canada through the Initiatives on the New Economy program, Human Resources and Skills Development Canada and HEC Montréal. The usual caveat applies.

${ }^{\dagger}$ Corresponding author : Institute of Applied Economics, HEC Montréal, University of Montréal, Montréal (Québec), H3T 2A7 ; IZA, CIRANO, CIRPÉE and CREF;

$\ddagger$ Center for Economic Studies, CESifo and University of Munich; jayaraman@lmu.de

$\S$ Kellogg School of Management, Northwestern University, Evanston (Illinois); mtrepanier@kellogg.northwestern.edu
\end{abstract} benoit.dostie@hec.ca 


\section{Introduction}

The question of whether or not there exists a premium to computer use was famously addressed by Krueger (1993) who concluded, using cross-sectional data from the U.S., that computer users earned a 15 to 20 per cent wage premium over nonusers. This figure was widely quoted until DiNardo and Pischke (1997) cast a shadow of doubt over Krueger's methodology. Using cross-sectional data from Germany, DiNardo and Pischke (1997) observed that computer users enjoyed a similar wage premium, but so did workers who used pencils or pens and those who sat down while working. Since such tools as writing implements and chairs are, in and of themselves, unlikely to yield large increases in productivity, they interpreted their findings as suggestive evidence that the observed computer premium may simply be a return to unobserved skills.

In North America, the debate regarding whether or not computer users enjoy a wage premium has pretty much languished there. ${ }^{1}$ This is unfortunate: given that computers arguably constitute the single most pervasive manifestation of skill-biased technological change, and skill-biased technological change is widely thought to be responsible for widening wage disparities observed in the U.S. and Canada since the 1970s, it is important to understand whether or not there exists a direct link between computers and wages. ${ }^{2}$

There is widespread consensus regarding what the data do not conclusively say, but there has been virtually no exploration of what they do actually say. Indeed, there appears to be something of a consensus based on Dinardo and

\footnotetext{
${ }^{1}$ Several recent papers have examined the effect of technological change on individual wages using European data. Dolton and Makepeace (2004) find a computer wage premium of 10$13 \%$ in Britain, while Anger and Schwarze (2003) in Germany, and Entorf and Kramarz (1997) and Entorf, Gollac, and Kramarz (1999) in France find no significant premium. Of these only the last 2 utilise a matched employer-employe dataset, allowing one to correct for worker and workplace unobserved components and only the last paper corrects for these two simultaneously. We compare our results in Section 4.

${ }^{2}$ Acemoglu (2002) provides a comprehensive review of the literature on technological change and wage inequality and a lucid analysis of the main arguments.
} 
Pischke's (1997) suggestive evidence that the returns to computer use are negligible, if not zero.

Data limitations are probably the main culprit for the neglect of this issue. The most obvious way to explore whether the worker selection problem is responsible for observed wage differentials or whether these wage differentials are "real", is by resorting to panel data containing information on both worker wages and computer use, and in North America such data are rare.

In this paper, we exploit a unique new (1999-2002) data set - the Canadian Workplace and Employee Survey (WES) - to examine the question of whether or not there exists a wage premium associated with computer use. WES is a longitudinal, matched employer-employee data set, containing remarkably detailed information on workers and their workplaces.

The fact that we observe the same worker over time permits us to correct for the worker selection problem, thereby directly examining DiNardo and Pischke's hunch for the first time in the North American context. In addition, the fact that the data are linked enables us to correct for workplace unobserved heterogeneity - a problem which was not the main focus of Dinardo and Pischke's (1997) critique, but one with which Krueger (1993) grappled. We accomplish this by employing mixed effects methods as suggested by Abowd and Kramarz (1999b). ${ }^{3}$

In the cross-section, using Krueger's (1993) specification, we find that computer use is associated with a 22 per cent wage premium. This number drops to just over 10 per cent once we correct for a rich array of observable characteristics, including experience with computer use. Once we correct for individual and workplace unobserved heterogeneity, the computer wage premium drops to

\footnotetext{
${ }^{3}$ To use standard fixed effects, we would have to observe the same worker in different firms - a feature our data does not permit, therefore necessitating the use of this somewhat involved mixed model. We argue later, however, that fixed effects methods may not be appropriate with short panels characterised by little variation. It is also worth noting that this mixed model does not require the orthogonality conditions pertaining to the unobserved components typically demanded of random effects models. Moreover, it can be shown that fixed effects estimates are a special case of mixed model estimates (see Abowd and Kramarz (1999b).)
} 
3.8 per cent.

Our findings lend credence to DiNardo and Pischke (1997)'s suspicion: allowing for the possibility of worker selection roughly halves the computer wage premium. Interestingly, correcting for workplace effects also leads to a substantial reduction in the observed premium, suggesting that the large computer wage premium observed in the cross-section may reflect not only individual, but also workplace unobserved heterogeneity, perhaps mediated through managerial ability. Still, the fact that computer users in our data enjoy an almost 4 per cent wage premium relative to a non-user, even after our various corrections for unobservable as well as observable heterogeneity, as well as significant returns to experience with computers suggests that there remains a sizeable return to computer use.

The remainder of the paper is organized as follows. Section 2 outlines our statistical framework, detailing our mixed model. Section 3 describes our data. In Section 4 we discuss our results, and Section 5 concludes.

\section{Statistical Model}

In order to take into account both individual and workplace heterogeneity in our model of wage determination, we use a two-factor analysis of covariance with repeated observations along the lines of Abowd and Kramarz (1999b): ${ }^{4}$

$$
y_{i t}=\mu+\mathbf{x}_{i t} \boldsymbol{\beta}+\theta_{i}+\psi_{j(i, t)}+\epsilon_{i t}
$$

with

$$
\theta_{i}=\alpha_{i}+\mathbf{u}_{i} \boldsymbol{\eta}
$$

\footnotetext{
${ }^{4}$ Details about the model, estimation procedure as well as properties of the estimators described in this can be found in Abowd and Kramarz (1999b)
} 
where $y_{i t}$ is the $(\log )$ wage rate observed for individual $i=1, \ldots, N$ at time $t=1, \ldots, T_{i}$. Person effects are denoted by $i$, workplace effects by $j$ as a function of $i$ and $t$, and time effects by $t . \mu$ is a constant, $\mathbf{x}_{i t}$ is a matrix containing demographic information for worker $i$ at time $t$ as well as information concerning workplace $j$ to which worker $i$ is linked. Although $\beta$ and $\eta$ can be fixed or random, we assume they are fixed in our estimations. All other effects are random. Personal heterogeneity $\left(\theta_{i}\right)$ is a measure of unobserved $\left(\alpha_{i}\right)$ and observed $\left(\mathbf{u}_{i} \boldsymbol{\eta}\right)$ time-invariant worker characteristics. Employer heterogeneity $\left(\psi_{j}\right)$ captures workplace-specific unobserved characteristics, common to all workers of the same workplace. $\epsilon_{i t}$ is the statistical residual.

In full matrix notation, we have

$$
y=X \beta+U \eta+D \alpha+F \psi+\epsilon
$$

where: $y$ is the $N^{*} \times 1$ vector of earnings outcomes; $X$ is the $N^{*} \times q$ matrix of observable time-varying characteristics including the intercept; $\beta$ is a $q \times 1$ parameter vector; $U$ is the $N^{*} \times p$ matrix of time invariant person characteristics; $\eta$ is a $p \times 1$ parameter vector; $D$ is the $N^{*} \times N$ design matrix of the unobserved component for the person effect; $\alpha$ is the $N \times 1$ vector of person effects; $F$ is the $N^{*} \times J$ design matrix of the workplace effects; $\psi$ is the $J \times 1$ vector of pure workplace effects; and $\epsilon$ is the $N^{*} \times 1$ vector of residuals.

In order to distinguish firm from individual fixed effects, we would have to observe the same worker in different firms. Our sampling frame does not follow workers moving from firm to firm, therefore ruling out the option of treating both firm and individual effects as fixed. ${ }^{5}$ Instead, we employ a mixed model in which worker and firm effects are treated as random. This model is, however, distinct from standard random effects models in that some correlation

\footnotetext{
${ }^{5}$ This data constraint also precludes the inclusion of worker-firm match effects.
} 
is permitted between the design matrix of the worker and firm effects with other covariates. Our choice of a mixed specification is done without loss of generality since it can be shown that both ordinary least squares (OLS) and fixed effects estimates are a special case of the mixed model estimates.

Identification of the firm and worker random effects is made possible through the longitudinal and linked aspects of the data, as well as from distributional assumptions. From the data structure, individual effects are identified through repeated observations on each individual over time and firm effects, by repeated observations on workers from the same firm.

With respect to the distributional assumptions, $\alpha$ and $\psi$ are taken to be normally distributed:

$$
\left[\begin{array}{l}
\alpha \\
\psi \\
\epsilon
\end{array}\right] \sim \sim_{N}\left(\left[\begin{array}{l}
0 \\
0 \\
0
\end{array}\right],\left[\begin{array}{ccc}
\sigma_{\alpha}^{2} I_{N} & 0 & 0 \\
0 & \sigma_{\psi}^{2} I_{J} & 0 \\
0 & 0 & \Lambda
\end{array}\right]\right)
$$

where

$$
\Lambda=\left[\begin{array}{ccccc}
\Sigma_{1} & 0 & \ldots & & 0 \\
\ldots & \ldots & & & \ldots \\
0 & \ldots & \Sigma_{i} & \ldots & 0 \\
\ldots & & & \ldots & \ldots \\
0 & & \ldots & 0 & \Sigma_{N}
\end{array}\right]
$$

and

$$
\Sigma_{i}=V\left(\epsilon_{i}\right) .
$$

A detailed description of our estimation procedure is presented in the Appendix. Briefly, parameters estimates are obtained in two steps. We first use Restricted Maximum Likelihood (REML) to get parameter estimates for the variance components in (4). We then solve the so-called Henderson's Mixed 
Model Equations to get estimates for the other parameters in the full model (3). Solving the mixed equations simultaneously yield the Best Linear Unbiased Estimates (BLUE) of the fixed effects and Best Linear Unbiased Predictors (BLUP) of the random effects.

Two important points should be made about the estimates for $(\hat{\beta}, \hat{\eta}, \hat{\alpha}, \hat{\psi})$. First, mixed model solutions $(\hat{\beta}, \hat{\eta}, \hat{\alpha}, \hat{\psi})$ converge to the least squares solutions for the fixed effects as $|\Omega| \rightarrow \infty$ (if $\Lambda=\sigma_{\epsilon}^{2} I_{N^{*}}$ ). In this sense, fixed effects estimates are a special case of the mixed model solutions. Second, unlike the usual random effects specification considered in the econometric literature, (3) and (4) do not assume that the random effects are orthogonal to the design ( $X$ and $U$ ) of the fixed effects $(\beta$ and $\eta)$. That is we do not assume $X^{\prime} D=X^{\prime} F=$ $U^{\prime} D=U^{\prime} F=0$. If this were the case, we could solve for $\hat{\beta}$ and $\hat{\eta}$ independently of $\hat{\alpha}$ and $\hat{\psi}$.

\section{Data}

We use four years of data from the 1999-2002 versions of the Workplace and Employee Survey (WES) conducted by Statistics Canada. ${ }^{6}$ The survey is both longitudinal and linked in that it documents the characteristics of workers and workplaces over time. ${ }^{7}$ The target population for the "workplace" component of the survey is defined as the collection of all Canadian establishments which paid employees in March of the year of the survey, except for those located in Yukon, the Northwest Territories and Nunavut. The sample comes from the "Business Register" of Statistics Canada, which contains information on every business operating in Canada. Firms operating in fisheries, agriculture and cattle farming are also excluded.

\footnotetext{
${ }^{6}$ This is a restricted-access data set available in Statistics Canada Research Data Centers (RDC).

${ }^{7}$ Abowd and Kramarz (1999a) classify WES as a survey in which both the sample of workplaces and the sample of workers are cross-sectionally representative of the target population.
} 
For the employee component, the target population is the collection of all employees working, or on paid leave, in the workplace target population. Employees are sampled from an employees list provided by the selected workplaces. For every workplace, a maximum number of 24 employees is selected and for establishments with less than 4 employees, all employees are sampled. In the case of total non-response, respondents are withdrawn entirely from the survey and sampling weights are recalculated in order to preserve representativeness of the sample.

WES selects new employees and workplaces in odd years (at every third year for employees and at every fifth year for workplaces). We therefore observe workplaces for 4 consecutive years and workers for 2 consecutive years. In order to control for the design effect in our estimations, we utilise the final sampling weights for employees as recommended by Statistics Canada.

The data contain a rich set of variables describing both worker and workplace characteristics. Our dependent variable is captured through the natural logarithm of hourly wages. Our main variable of interest - computer user is a dummy variable which takes on value 1 (0) if the employee answers "yes" ("no") to the question "Do you use a computer in your job?", where computer is explicitly defined as "a microcomputer, mini-computer, personal computer, mainframe computer or laptop that can be programmed to perform a variety of operations". This is distinct from the use of computer-assisted devices (CAD), such as industrial robots and retail scanning systems, and also distinct from other technologies (Otech) such as cash registers, scanners or machinery, which we also correct for. Our computer use variable is therefore almost identical to the one Krueger (1993) used in his analysis and DiNardo and Pischke (1997) used in their $85-86$ and $91-92$ data. We also account for lifetime experience with a computer. To the extent that skills improve with practice, this variable 
may be interpreted as a proxy for computer skills.

Table 1 presents more details about the structure of WES with respect to computer use. 23,540 workers were sampled in 1999, 20,167 (85.6\%) of whom Statistics Canada was able to contact again in 2000. 20,352 employees were resampled in 2001 and 16,813 (82.6\%) of them were contacted again in 2002 . The total number of observations is thus 80,872 . Once we get rid of observations with missing values for some covariates, we are left with 78,925 observations and this is what we use for estimation purpose in our mixed

Table 2 describes changes in computer use among employees in our final sample of workers observed over two periods. 59 per cent of workers stayed computer users in both periods over which they were sampled, 3 per cent left computer use, 5 per cent entered computer use, and 31 per cent didn't use computers in either period. The fact that only 8 of our sample constitutes "switchers" highlights our difficulty, discussed at the end of Section 4, in reliably identifying a standard individual fixed effects model, thereby providing one additional ground for employing a mixed model specification.

We are fortunate to have almost all the standard demographic and workrelated indicators which Krueger (1993) included in his initial analysis, including race, gender, marital status, education, experience, residence, occupation, part-time employment and union status. In addition, we directly control for a number of variables which Krueger (1993) pointed to as potential sources of bias, including seniority, firm size and industry.

Table 3 shows the probability of computer use at work for various demographic categories in 1999. Tables 4 and 5 provide descriptive statistics for employees and their workplaces, respectively. (It is not possible for confidentiality reasons to show minima and maxima.)

Computer use in our data is, across the board, substantially higher, and 
changes in computer use, considerably lower than they are in either Krueger (1993) or DiNardo and Pischke (1997). The simple explanation for this is that our data are much more recent. ${ }^{8}$ The patterns of computer use are extremely similar in both countries. Females are more likely to use a computer than males, as are whites relative to blacks and nonunion members relative to union members. Computer use in both countries also rises monotonically with educational attainment. Computer use also varies considerably by occupation and industry as well as work experience.

\section{Returns to Computer Use}

Table 6 presents Weighted Least Squares (WLS) estimates for the returns to computer use in 1999 and 2001. Our specification as well as methodology mirrors Krueger (1993) to the extent possible. In columns 1 and 3, computer use is the only right hand side variable, while columns 2 and 4 correct for a number of worker characteristics.

Correcting for worker characteristics, the wage premium associated with computer use is just under 22 per cent, compared to Krueger's 20 per cent estimate for 1989. This number is striking, especially given the high degree of penetration at the turn of the century. Our results are also otherwise remarkably similar to Krueger (1993)'s . In particular, wages are increasing in education and work experience (at a decreasing rate). They are lower (in 2001) for Blacks and Other races relative to Whites, as they are for Women relative to Men. Married men as well as Union members, by contrast, tend to have higher earnings. All of this suggests that our data are well-placed to analyze the question, first posed by Krueger, "Is the computer wage differential real or illusory?". 9

\footnotetext{
${ }^{8}$ According to the 2001 Current Population Survey (CPS) - the data source used by Krueger (1993) - computer use in the U.S. among the industries covered by WES was 54 per cent.

${ }^{9}$ Krueger (1993), p. 42
} 
DiNardo and Pischke (1997)'s suggestion that the computer wage differential may be illusory arises primarily from the problem of endogeneity in the form of omitted variables. In table 7 we begin to address this by including a number of additional, observable, worker and workplace characteristics, many of which Krueger (1993) was only indirectly able to control for.

In the interest of comparability, our specification is constructed to mirror Entorf and Kramarz (1997) and Entorf, Gollac, and Kramarz (1999), who use French linked longitudinal employer-employee data of comparable structure to ours to examine the computer premium question. ${ }^{10}$ The pooled OLS results presented in Column 1 indicates that inclusion of these covariants, as anticipated, leads to a substantial reduction of the coefficient on computer use from 0.197 to 0.097 - a number comparable to the coefficient of 0.07 found by Entorf, Gollac, and Kramarz (1999) for France 7 years earlier. Our estimates also indicate that there exists a significant premium associated with computer experience. Taking this into account suggests that, according to our pooled OLS estimates, the average computer user (who has 6 years of computer experience) enjoys 19.2 per cent higher wages than non-users.

The pooled OLS estimator does not however correct for unobserved heterogeneity, only yielding consistent estimates if there is no correlation between unobserved characteristics and right hand side variables. If it is the case, for instance, that more able workers are more likely to be assigned a computer or more likely to work at computer technology-intensive firms, then this assumption will clearly be violated.

Columns 2-4 present the results of our mixed model, which corrects for unobserved heterogeneity while permitting for correlation between unobserved worker and workplace effects with other covariates. Columns 2 and 3 correct

\footnotetext{
${ }^{10}$ The coefficients on computer use and computer experience are robust to alternative specifications which include, among other things, a large number of organizational practices.
} 
for worker and workplace effects, respectively, while column 4 corrects for both.

Once we correct for worker effects, the coefficient on computer use, presented in column 2, drops from 0.097 to 0.046 . This suggests that the worker selection effect may account for roughly half of the observed computer wage premium. Interestingly, workplace effects also bear considerable responsibility for the upward bias: correcting for this leads to an almost 40 per cent drop in the premium, from 0.097 to 0.061 (column 3).

Correcting for both worker and workplace in column 4 yields a premium to computer use of 3.8 per cent, compared to the 10.2 per cent observed in our pooled OLS estimates. If our estimates are indeed completely correcting for unobserved heterogeneity, then this may be interpreted as the productivity gain associated with providing a worker with a computer.

Interestingly, the coefficient estimates pertaining to computer experience are not significantly different once one moves from the pooled OLS to the full mixed model, suggesting that this variable is not unduely affected by unobservable heterogeneity. Taking into account the significant returns associated with computer experience indicates that the average computer user (with 6 years of experience) earns a 13.2 per cent higher wages than a non-user.

The size of the coefficient in column 4 relative to those in columns 2 and 3 indicates that worker and workplace effects are positively correlated. This is suggestive of positive sorting between workers and workplaces who, for unobserved reasons, are more likely to use computers. In other words, high ability workers, who are more likely to be assigned a computer, match with high productivity firms which are more likely to invest in computers.

Although not the focus of this paper, it is worth noting that our results are in marked contrast to those of Entorf, Gollac, and Kramarz (1999), who find (in their Table 5) that correcting for individual and firm fixed effects yields insignif- 
icant coefficients on the computer use variable. Two obvious explanations are time and space. Our data are separated by 7 years, a period of time over which firms were no doubt confronted with new developments in terms of complementary innovations or cost reduction alternatives affecting both IT adoption and worker productivity. Moreover, the data pertain to two different continents with different institutional structures governing both industry and labour.

Another explanation, however, lies in the fact that Entorf, Gollac, and Kramarz (1999) use fixed effects whereas we use mixed effects. Fixed effects models have a distinct advantage over mixed effects to the extent that they do not impose additional distributional assumptions. However, since they are identified via "switchers", their coefficient estimates tend to be imprecise over short panels with relatively little variation. This is certainly the case in our data. Our data follow workers for only 2 years, and when we estimate individual fixed effects, our standard errors typically rise and our returns to computer use are not significantly different from zero. ${ }^{11}$ Since Entorf, Gollac, and Kramarz (1999) workers are followed for at most 3 years this is a problem which they must also, to some extent, face.

The main advantage of our mixed- over a fixed-effects model it that it does not rely on "switchers" for identification, thus yielding more precise estimates even with relatively short panels. ${ }^{12}$ Moreover, a comparison of coefficients in our mixed model and a model with fixed workplace effects suggests similar implied biases relative to our pooled OLS estimates. ${ }^{13}$ Given that our fixed workplace estimates are relatively more precise than our fixed worker estimates, given our longer (4 year) workplace panel, this suggests that the mixed model

\footnotetext{
${ }^{11}$ Fixed effects estimation results are available from the authors upon request.

${ }^{12}$ Furthermore, the fixed effects model relies upon the assumption that staying, leaving and entering computer use each have the same effect on wages. A simple test for this along the lines of Jakubson (1991) and Dolton and Makepeace (2004) leads to the rejection of this assumption for our data, suggesting that fixed effects estimates would be biased in this context.

${ }^{13} \mathrm{In}$ the workplace fixed effects model, the implied bias is $9.7 \%-5.1 \%=4.6 \%$ compared to $9.7 \%-6.1 \%=3.6 \%$ in the workplace mixed model presented in column 3 of Table 7 .
} 
does a rather good job of controlling for unobserved heterogeneity, at least at the workplace level. Finally, it should be noted that we can rely on another source of identification when using workplace fixed effects, namely variation in wages and computer use within the workplace.

\section{Discussion}

Is there a real computer wage differential? We find that there is. The computer wage premium in our data is 3.8 per cent. In addition, the fact that there are significant returns associated with computer experience means that the wage differential between the average computer user and non-users is 13 per cent.

At the same time, DiNardo and Pischke (1997) were quite right to worry about the individual selection problem in estimating the computer wage premium. Failure to correct for individual unobserved heterogeneity, results in an observed premium which is more than double the estimated 3.8 per cent.

We find that failure to correct for workplace effects also results in a significant overestimate of the computer wage premium. Although the literature to date has focused almost exclusively on worker effects, this finding need not be particularly surprising. Workplaces run by managers with high unobserved ability, for instance, may be more likely to both invest in computers (especially if these are cost-cutting instruments) and have a relatively productive workforce. Alternatively, firms operating in certain product markets may require both special skills (for which higher wages are paid) and relatively high computer use as a factor input.

The most natural stories which explain the mixed model estimates in our data involve high ability workers matching with high productivity firms which are more likely to invest in computers. And this positive sorting, too, finds support in our data, lending corroborative evidence to inter-industry studies 
which have found that more computerised industries tend to employ more skilled (and presumably more able) workers (Berman, Bound, and Griliches (1994), Autor, Katz, and Krueger (1998) and Machin and Reenen (1998).)

The initial motivation behind Krueger's study was to examine whether computers have changed the wage structure. It would be presumptuous at best to conclude, on the basis of our data, that they have. After all, according to our estimates, the returns to computer use are slightly smaller than those to having completed highschool, and nobody is arguing that a larger proportion of highschool graduates is what is driving rising wage inequality.

Nevertheless, the presence of a computer wage differential, maintained in part by substantial returns to computer experience, may provide one possible explanation for why the U.S. and Canada have witnessed sustained wage inequality through the turn of the century, at a time when the supply of college graduates seems to have levelled off and the major skill-biased technological changes at the workplace are arguably well behind us.

\section{References}

Abowd, J. M. and F. Kramarz (1999a). The analysis of labor markets using matched employer-employee data. In O. Ashenfelter and D. Card (Eds.), Handbook of Labor Economics, Volume 3B, pp. 2629-2710. Elsevier Science, North-Holland.

Abowd, J. M. and F. Kramarz (1999b). Econometric analyses of linked employer-employee data. Labour Economics 6(1), 53-74.

Acemoglu, D. (2002). Technical change, inequality and the labour market. Journal of Economic Literature 40(1), 7-72.

Anger, S. and J. Schwarze (2003). Does future pc use determine our wages 
today? evidence from german panel data. Labour 17(3), 337-360.

Autor, D. H., L. F. Katz, and A. B. Krueger (1998). Computing inequality: Have computers changed the labor market? Quarterly Journal of Economics 113(4), 1169-1213.

Berman, E., J. Bound, and Z. Griliches (1994). Changes in the demand for skilled labor within U.S. manufacturing: Evidence from the annual survey of manufacturers. Quarterly Journal of Economics 109(2), 367-397.

DiNardo, J. E. and J.-S. Pischke (1997). The returns to computer use revisited: Have pencils changed the wage structure too? Quarterly Journal of Economics 112(1), 291-303.

Dolton, P. and G. Makepeace (2004). Computer use and earnings in britain. The Economic Journal 114(1), C117-C129.

Entorf, H., M. Gollac, and F. Kramarz (1999). New technologies, wages, and workers selection. Journal of Labor Economics 17(3), 464-491.

Entorf, H. and F. Kramarz (1997). Does unmeasured ability explain the higher wages of new technology workers? European Economic Review 41, 14891509.

Jakubson, G. H. (1991). Estimation and testing of the union wage effect using panel data. Review of Economic Studies 58, 971-991.

Krueger, A. B. (1993). How computers have changed the wage structure: Evidence from microdata. Quarterly Journal of Economics 108(1), 3360.

Machin, S. and J. V. Reenen (1998). Technology and changes in skill structure: Evidence from seven OECD countries. Quarterly Journal of Economics 113, 1215-1244. 
Table 1: Movers versus Stayers

\begin{tabular}{lccccc}
\hline \hline Computer Use & \multicolumn{2}{c}{1999 only } & \multicolumn{2}{c}{$1999-2000$} & Total \\
\hline \multirow{2}{*}{ No } & $\#$ & $\%$ & $\#$ & $\%$ & $\#$ \\
\cline { 2 - 6 } One period only & 1463 & 0.43 & 6084 & 0.30 & \\
Both periods & 1910 & 0.57 & 2188 & 0.11 & \\
\hline Total & & & 11895 & 0.59 & \\
\hline \multicolumn{7}{c}{3373} & 1.00 & 20167 & 1.00 & 23540 \\
\hline Computer Use & 2001 only & $2001-2002$ & \\
\hline \multirow{3}{*}{ No } & $\#$ & $\%$ & $\#$ & $\%$ & $\#$ \\
One period only & 2081 & 0.59 & 1910 & 0.11 & \\
Both periods & & & 9742 & 0.58 & \\
\hline Total & 3539 & 1.00 & 16813 & 1.00 & 20352 \\
\hline \hline
\end{tabular}

Table 2: Stay, Leave and Enter

\begin{tabular}{lcc}
\hline \hline Computer Use & \multicolumn{2}{c}{$1999-2000$ or $2001-2002$} \\
\cline { 2 - 3 } Stay & $\#$ & $\%$ \\
Leave & 21637 & 0.59 \\
Enter & 1200 & 0.03 \\
None & 1849 & 0.05 \\
Total & 35931 & 0.31 \\
\hline \hline
\end{tabular}


Table 3: Computer usage in 1999

\begin{tabular}{lr}
\hline \hline All workers & 60.8 \\
Men & 57.9 \\
Women & 63.5 \\
White & 60.9 \\
Black & 54.8 \\
Other races & 60.7 \\
Union status & \\
Union member & 51.5 \\
Nonunion & 64.4 \\
Schooling & \\
Less than high school & 34.0 \\
High school & 52.1 \\
Some college & 65.0 \\
College & 66.5 \\
Post college & 83.7 \\
Occupations & \\
Manager & 81.9 \\
Professional & 84.7 \\
Technician/trades & 46.3 \\
Marketing/sales & 41.2 \\
Clerical/administrative & 85.9 \\
Production without certificate & 64.8 \\
Industries & 63.9 \\
Forestry, mining, oil, and gas extraction & 54.9 \\
Primary product manufacturing & 49.6 \\
Secondary product manufacturing & 56.4 \\
Labour intensive tertiary manufacturing & 40.0 \\
Capital intensive tertiary manufacturing & 67.6 \\
Construction & 37.6 \\
Transportation, warehousing, wholesale & 65.5 \\
Communication and other utilities & 66.8 \\
Retail trade and consumer services & 47.2 \\
Finances and insurance & 93.9 \\
Real estate, rental and leasing operations & 65.9 \\
Education and health services & \\
Information and cultural industries & \\
Business services & \\
Work Experience & \\
\hline
\end{tabular}


Table 4: Descriptive statistics - Employees

\begin{tabular}{|c|c|c|c|c|}
\hline \multirow[b]{3}{*}{$\ln$ (hourly wage) } & \multicolumn{2}{|c|}{1999} & \multicolumn{2}{|c|}{2001} \\
\hline & Mean & Std Dev & Mean & Std Dev \\
\hline & 2.778 & 0.521 & 2.820 & 0.530 \\
\hline \multicolumn{5}{|l|}{ Highest completed degree } \\
\hline Less then high school & 0.107 & 0.309 & 0.120 & 0.325 \\
\hline High school & 0.175 & 0.380 & 0.179 & 0.384 \\
\hline Industry training & 0.053 & 0.162 & 0.033 & 0.365 \\
\hline Trade or vocational diploma & 0.088 & 0.283 & 0.098 & 0.297 \\
\hline Some college & 0.104 & 0.305 & 0.108 & 0.310 \\
\hline Completed college & 0.181 & 0.385 & 0.188 & 0.391 \\
\hline Some university & 0.077 & 0.266 & 0.067 & 0.249 \\
\hline Teacher's college & 0.002 & 0.049 & 0.001 & 0.030 \\
\hline University certificate & 0.018 & 0.132 & 0.020 & 0.138 \\
\hline Bachelor degree & 0.130 & 0.337 & 0.133 & 0.339 \\
\hline University certificate ( $>$ bachelor) & 0.019 & 0.135 & 0.015 & 0.120 \\
\hline Master's degree & 0.031 & 0.174 & 0.028 & 0.165 \\
\hline Degree in medicine, dentistry, etc. & 0.008 & 0.092 & 0.007 & 0.085 \\
\hline Earned doctorate & 0.006 & 0.078 & 0.005 & 0.067 \\
\hline Seniority (years) & 8.517 & 8.206 & 8.518 & 8.206 \\
\hline Work Experience (years) & 16.167 & 10.714 & 16.411 & 10.993 \\
\hline Black & 0.011 & 0.104 & 0.014 & 0.119 \\
\hline Other races & 0.280 & 0.449 & 0.309 & 0.462 \\
\hline Women & 0.521 & 0.500 & 0.506 & 0.500 \\
\hline Married & 0.566 & 0.496 & 0.541 & 0.498 \\
\hline Computer user & 0.608 & 0.488 & 0.601 & 0.490 \\
\hline $\mathrm{CAD}$ & 0.120 & 0.325 & 0.133 & 0.340 \\
\hline Otech & 0.269 & 0.443 & 0.228 & 0.420 \\
\hline Computer Experience (years) & 5.865 & 6.373 & 6.483 & 6.732 \\
\hline Union member & 0.279 & 0.449 & 0.280 & 0.449 \\
\hline Part-time & 0.051 & 0.220 & 0.053 & 0.224 \\
\hline \multicolumn{5}{|l|}{ Occupations } \\
\hline Manager & 0.151 & 0.358 & 0.112 & 0.315 \\
\hline Professional & 0.162 & 0.368 & 0.175 & 0.380 \\
\hline Trader/Technician & 0.390 & 0.488 & 0.414 & 0.493 \\
\hline Marketing/sales & 0.084 & 0.277 & 0.085 & 0.279 \\
\hline Clerical/administrative & 0.140 & 0.347 & 0.137 & 0.344 \\
\hline Production w/o certificate & 0.074 & 0.262 & 0.077 & 0.267 \\
\hline Number of employees: & \multicolumn{2}{|c|}{23540} & \multicolumn{2}{|c|}{20352} \\
\hline
\end{tabular}


Table 5: Descriptive statistics - Workplaces

\begin{tabular}{lcc}
\hline \hline & \multicolumn{2}{c}{1999} \\
\cline { 2 - 3 } Industry & Mean & Std Dev. \\
\cline { 2 - 3 } Natural resources & 0.019 & 0.136 \\
Primary manufacturing & 0.010 & 0.100 \\
Secondary manufacturing & 0.017 & 0.130 \\
Labour tertiary & 0.031 & 0.173 \\
Capital tertiary & 0.023 & 0.150 \\
Construction & 0.077 & 0.267 \\
Transport & 0.121 & 0.326 \\
Communication & 0.013 & 0.111 \\
Retail & 0.318 & 0.466 \\
Finance and insurance & 0.052 & 0.222 \\
Real estate & 0.043 & 0.203 \\
Business services & 0.112 & 0.317 \\
Education and health services & 0.141 & 0.348 \\
Culture and information & 0.022 & 0.147 \\
Workplace size & \multicolumn{2}{c}{0.331} \\
Tiny (1-9 employees) & 0.874 & 0.310 \\
Small (10-99 employees) & 0.108 & 0.122 \\
Medium (100-499 employees) & 0.015 & 0.050 \\
Large ( $\geqslant 500$ employees) & 0.003 \\
\hline Number of workplaces: & \multicolumn{2}{c}{6322} \\
\hline \hline
\end{tabular}


Table 6: Impact of Computer Use in Basic Linear Models

\begin{tabular}{|c|c|c|c|c|}
\hline & \multicolumn{2}{|c|}{1999} & \multicolumn{2}{|c|}{2001} \\
\hline & $(1)$ & $(2)$ & $(3)$ & $(4)$ \\
\hline Intercept & $\begin{array}{c}2.575^{* * *} \\
(0.012)\end{array}$ & $\begin{array}{c}2.415^{* * *} \\
(0.034)\end{array}$ & $\begin{array}{c}2.585^{* * *} \\
(0.012)\end{array}$ & $\begin{array}{c}2.519^{* * *} \\
(0.032)\end{array}$ \\
\hline Computer User & $\begin{array}{c}0.330^{* * *} \\
(0.015)\end{array}$ & $\begin{array}{c}0.195^{* * *} \\
(0.015)\end{array}$ & $\begin{array}{c}0.384^{* * *} \\
(0.016)\end{array}$ & $\begin{array}{c}0.197^{* * *} \\
(0.014)\end{array}$ \\
\hline High school & & $\begin{array}{c}0.097^{* * *} \\
(0.020)\end{array}$ & & $\begin{array}{c}0.075^{* * *} \\
(0.020)\end{array}$ \\
\hline Less than Graduate & & $\begin{array}{c}0.138^{* * *} \\
(0.017)\end{array}$ & & $\begin{array}{c}0.162^{* * *} \\
(0.018)\end{array}$ \\
\hline Bachelor & & $\begin{array}{c}0.263^{* * *} \\
(0.045)\end{array}$ & & $\begin{array}{c}0.305^{* * *} \\
(0.047)\end{array}$ \\
\hline Higher ed. & & $\begin{array}{c}0.337^{* * *} \\
(0.024)\end{array}$ & & $\begin{array}{c}0.397^{* * *} \\
(0.023)\end{array}$ \\
\hline Work Experience & & $\begin{array}{c}0.020^{* * *} \\
(0.002)\end{array}$ & & $\begin{array}{c}0.025^{* * *} \\
(0.002)\end{array}$ \\
\hline Work Experience squared (/100) & & $\begin{array}{c}-0.029 * * * \\
(0.006)\end{array}$ & & $\begin{array}{c}-0.044 * * * \\
(0.004)\end{array}$ \\
\hline Black & & $\begin{array}{l}-0.037 \\
(0.055)\end{array}$ & & $\begin{array}{c}-0.080 * * * \\
(0.027)\end{array}$ \\
\hline Other races & & $\begin{array}{l}-0.010 \\
(0.012)\end{array}$ & & $\begin{array}{c}-0.023^{*} \\
(0.013)\end{array}$ \\
\hline Part-time & & $\begin{array}{c}0.024 \\
(0.019)\end{array}$ & & $\begin{array}{c}-0.060 * * * \\
(0.020)\end{array}$ \\
\hline Women & & $\begin{array}{c}-0.124^{* * *} \\
(0.019)\end{array}$ & & $\begin{array}{c}-0.124^{* * *} \\
(0.017)\end{array}$ \\
\hline Married & & $\begin{array}{c}0.142^{* * *} \\
(0.019)\end{array}$ & & $\begin{array}{c}0.122^{* * *} \\
(0.017)\end{array}$ \\
\hline Married ${ }^{*}$ women & & $\begin{array}{c}-0.050^{* *} \\
(0.025)\end{array}$ & & $\begin{array}{c}-0.079 * * * \\
(0.023)\end{array}$ \\
\hline Union member & & $\begin{array}{c}0.187^{* * *} \\
(0.012)\end{array}$ & & $\begin{array}{c}0.166^{* * *} \\
(0.011)\end{array}$ \\
\hline Occupation dummies (6) & No & Yes & No & Yes \\
\hline R-squared & 0.10 & 0.42 & 0.13 & 0.49 \\
\hline Sample size & & & & \\
\hline
\end{tabular}

Statistical significance: ${ }^{*}=10 \% ;{ }^{* *}=5 \% ; * * *=1 \%$

Robust standard errors in parentheses. 
Table 7: Impact of Computer Use in OLS and Mixed-Effects Models

\begin{tabular}{lcccc}
\hline \hline & Pooled OLS & \multicolumn{3}{c}{ Mixed effects } \\
\cline { 2 - 5 } & & Worker & Workplace & Both \\
\hline Intercept & $2.663^{* * *}$ & $2.699^{* * *}$ & $2.804^{* * *}$ & $2.772^{* * *}$ \\
& $(0.023)$ & $(0.013)$ & $(0.019)$ & $(0.017)$ \\
Computer User & $0.097^{* * *}$ & $0.046^{* * *}$ & $0.061^{* * *}$ & $0.037^{* * *}$ \\
CAD & $(0.009)$ & $(0.003)$ & $(0.004)$ & $(0.003)$ \\
& 0.011 & 0.007 & 0.008 & 0.008 \\
OTech & $(0.009)$ & $(0.003)$ & $(0.004)$ & $(0.003)$ \\
& $-0.019^{* * *}$ & -0.003 & $-0.011^{* * *}$ & -0.002 \\
High school & $(0.007)$ & $(0.002)$ & $(0.003)$ & $(0.002)$ \\
& $0.072^{* * *}$ & $0.063^{* * *}$ & $0.050^{* * *}$ & $0.049^{* * *}$ \\
Less than graduate & $(0.010)$ & $(0.006)$ & $(0.005)$ & $(0.006)$ \\
& $0.117^{* * *}$ & $0.112^{* * *}$ & $0.087^{* * *}$ & $0.084^{* * *}$ \\
Bachelor & $(0.009)$ & $(0.006)$ & $(0.004)$ & $(0.005)$ \\
& $0.210^{* * *}$ & $0.202^{* * *}$ & $0.171^{* * *}$ & $0.168^{* * *}$ \\
Higher ed. & $(0.024)$ & $(0.012)$ & $(0.009)$ & $(0.011)$ \\
& $0.308^{* * *}$ & $0.320^{* * *}$ & $0.238^{* * *}$ & $0.264^{* * *}$ \\
Work Experience & $(0.012)$ & $(0.007)$ & $(0.005)$ & $(0.007)$ \\
& $0.016^{* * *}$ & $0.017^{* * *}$ & $0.013^{* * *}$ & $0.015^{* * *}$ \\
Work Experience squared $(/ 100)$ & $(0.001)$ & $(0.001)$ & $(0.000)$ & $(0.001)$ \\
& $-0.030^{* * *}$ & $-0.030^{* * *}$ & $-0.024^{* * *}$ & $-0.025^{* * *}$ \\
Computer Experience & $(0.003)$ & $(0.001)$ & $(0.001)$ & $(0.001)$ \\
& $0.012^{* * *}$ & $0.016^{* * *}$ & $0.010^{* * *}$ & $0.012^{* * *}$ \\
Computer Experience squared $(/ 100)$ & $(0.002)$ & $(0.001)$ & $(0.001)$ & $(0.001)$ \\
& $-0.024^{* * *}$ & $-0.035^{* * *}$ & $-0.019^{* * *}$ & $-0.025^{* * *}$ \\
Seniority & $(0.006)$ & $(0.003)$ & $(0.002)$ & $(0.003)$ \\
Seniority squared $(/ 100)$ & $0.013^{* * *}$ & $0.010^{* * *}$ & $0.012^{* * *}$ & $0.010^{* * *}$ \\
& $(0.001)$ & $(0.001)$ & $(0.000)$ & $(0.001)$ \\
& $-0.022^{* * *}$ & $-0.013^{* * *}$ & -0.020 & $-0.015^{* * *}$ \\
\hline \hline & $(0.003)$ & $(0.002)$ & $(0.001)$ & $(0.002)$ \\
\hline
\end{tabular}


Table 7: Cont'd

\begin{tabular}{|c|c|c|c|c|}
\hline & \multirow[t]{2}{*}{ Pooled OLS } & \multicolumn{3}{|c|}{ Mixed effects } \\
\hline & & Worker & Workplace & Both \\
\hline \multirow[t]{2}{*}{ Black } & $-0.069 * * *$ & $-0.084^{* * *}$ & $-0.061^{* * *}$ & $-0.072^{* * *}$ \\
\hline & $(0.019)$ & $(0.018)$ & $(0.011)$ & $(0.016)$ \\
\hline \multirow[t]{2}{*}{ Other races } & 0.003 & -0.004 & $-0.015^{* * *}$ & $-0.020 * * *$ \\
\hline & $(0.006)$ & $(0.004)$ & $(0.003)$ & $(0.004)$ \\
\hline \multirow[t]{2}{*}{ Part-time } & 0.001 & $0.021 * * *$ & $0.026^{* * *}$ & $0.029 * * *$ \\
\hline & $(0.010)$ & $(0.004)$ & $(0.004)$ & $(0.004)$ \\
\hline \multirow[t]{2}{*}{ Women } & $-0.117^{* * *}$ & $-0.142^{* * *}$ & $-0.114^{* * *}$ & $-0.123^{* * *}$ \\
\hline & $(0.009)$ & $(0.005)$ & $(0.004)$ & $(0.005)$ \\
\hline \multirow[t]{2}{*}{ Married } & $0.083^{* * *}$ & $0.071^{* * *}$ & $0.071^{* * *}$ & $0.068 * * *$ \\
\hline & $(0.009)$ & $(0.005)$ & $(0.004)$ & $(0.004)$ \\
\hline \multirow[t]{2}{*}{ Married * women } & $-0.043^{* * *}$ & $-0.042^{* * *}$ & $-0.033^{* * *}$ & $-0.039 * * *$ \\
\hline & $(0.012)$ & $(0.006)$ & $(0.005)$ & $(0.006)$ \\
\hline \multirow[t]{2}{*}{ Union member } & $0.063^{* * *}$ & $0.085^{* * *}$ & $0.033^{* * *}$ & $0.073^{* * *}$ \\
\hline & $(0.007)$ & $(0.004)$ & $(0.004)$ & $(0.004)$ \\
\hline \multirow[t]{2}{*}{ Small size } & $0.062^{* * *}$ & $0.065^{* * *}$ & $0.052^{* * *}$ & $0.055^{* * *}$ \\
\hline & $(0.008)$ & $(0.004)$ & $(0.006)$ & $(0.005)$ \\
\hline \multirow[t]{2}{*}{ Average size } & $0.137^{* * *}$ & $0.125^{* * *}$ & $0.129 * * *$ & $0.116^{* * *}$ \\
\hline & $(0.008)$ & $(0.005)$ & $(0.007)$ & $(0.006)$ \\
\hline \multirow[t]{2}{*}{ Large size } & $0.185^{* * *}$ & $0.181^{* * *}$ & $0.193^{* * *}$ & $0.166^{* * *}$ \\
\hline & $(0.009)$ & $(0.006)$ & $(0.01)$ & $(0.009)$ \\
\hline Year dummies (4) & Yes & Yes & Yes & Yes \\
\hline Occupation dummies (6) & Yes & Yes & Yes & Yes \\
\hline Region dummies (7) & Yes & Yes & Yes & Yes \\
\hline Industry dummies (14) & Yes & Yes & Yes & Yes \\
\hline R-squared & 0.56 & & & \\
\hline Sample size & 78925 & 78925 & 78925 & 78925 \\
\hline
\end{tabular}

Statistical significance: ${ }^{*}=10 \% ; * *=5 \% ; * * *=1 \%$.

Robust standard errors in parentheses. 


\section{A Appendix: Estimation}

REML methods involve applying maximum likelihood (ML) to linear functions of $y$, i.e. $K^{\prime} y$ (McCulloch and Searle (2001)). Note that $K^{\prime}$ is specifically designed so that $K^{\prime} y$ contains none of the fixed effects ( $\beta$ and $\eta$ in our case) which are part of the model for $y$. Thus, REML is simply ML applied on $K^{\prime} y$ and can be interpreted as maximizing a marginal likelihood.

Each vector of $K$ is chosen so that $k^{\prime} y=0$ or $K^{\prime}\left[\begin{array}{ll}X & U\end{array}\right]=0$. With $y \sim N(X \beta+U \eta, V)$ it follows that

$$
K^{\prime} y \sim N\left(0, K^{\prime} V K\right)
$$

where $V=D D^{\prime} \sigma_{\alpha}^{2}+F F^{\prime} \sigma_{\psi}^{2}+\Lambda$ is the covariance of earnings implied by the assumptions we made about the distribution of the unobserved heterogeneity terms. The REML log-likelihood is therefore

$$
\log L_{R E M L}=-\frac{1}{2}\left(N^{*}-r\right) \log 2 \pi-\frac{1}{2} \log \left|K^{\prime} V K\right|-\frac{1}{2} y^{\prime} K\left(K^{\prime} V K\right)^{-1} K^{\prime} y
$$

There are two advantages of using REML. First, variance components are estimated without being affected by the fixed effects. This means that the variance estimates are invariant to the values of the fixed effects. Second, in estimating variance components with REML, degrees of freedom for the fixed effects are taken into account implicitly whereas with ML they are not. ${ }^{1}$ Both methods have the same merits of being based on the maximum likelihood principle and parameter estimates inherit the consistency, efficiency, asymptotic normality and invariance properties that follow.

Maximization of the likelihood function (1), while providing us with esti-

${ }^{1}$ REML estimates are also invariant to whatever set of contrasts is chosen for $K^{\prime} y$ as long as $K^{\prime}$ is of full rank (Searle, Casella, and McCulloch (1992)). 
mates for the variance components, will not yield estimates for the random and fixed effects. In a second step, we obtain estimates for the random and fixed effects using a set of equations developed by Henderson, Kempthorne, Searle, and Krosigk (1959). These equations have become known as Henderson's Mixed Model Equations (MME) and simultaneously yield the Best Linear Unbiased Estimates (BLUE) of the fixed effects and Best Linear Unbiased Predictors (BLUP) of the random effects for known values of the variance components and $\Lambda^{2}$. Define the matrix of variance components as

$$
\Omega=\left[\begin{array}{cc}
\sigma_{\alpha}^{2} I_{N} & 0 \\
0 & \sigma_{\psi}^{2} I_{J}
\end{array}\right]
$$

For the particular structure implied by the model, the MME are

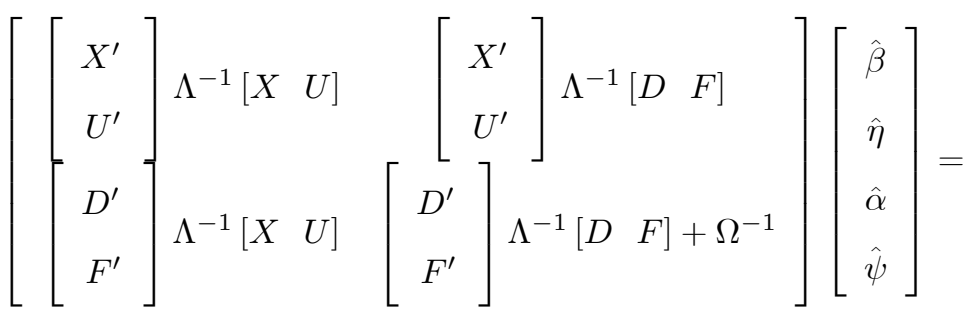

$$
\begin{aligned}
& \left.=\left[\begin{array}{c}
X^{\prime} \\
U^{\prime} \\
D^{\prime} \\
F^{\prime}
\end{array}\right] \Lambda^{-1} y\right]
\end{aligned}
$$

Estimates for $\Lambda$ and $\Omega$ are obtained from the REML step.

\footnotetext{
${ }^{2}$ BLUE and BLUP estimates make us feel quite confident that a full information approach would not yield any better (in the sense of lower variance) estimator, although it might if we were to use a different class of estimators.
} 


\section{References}

Henderson, C., O. Kempthorne, S. Searle, and C. Krosigk (1959). The estimation of environmental and genetic trends from records subject to culling. Biometrics 15(2), 192-218.

McCulloch, C. and S. Searle (2001). Generalized, Linear and Mixed Models. Wiley Series in Probability and Statistics, John Wiley and Sons Inc.

Searle, S. R., G. Casella, and C. McCulloch (1992). Variance Components. New York: John Wiley and Sons. 


\section{Liste des cahiers de recherche publiés par les professeurs des H.E.C. 2005-2006}

\section{Institut d'économie appliquée}

IEA-05-01 DÉSIRÉ VENCATACHALLUM ET BRUNO VERSAEVEL. « R\&D Delegation in a Duopoly with Spillovers », 57 pages.

IEA-05-02 MiCHEL NORMANDIN ET PASCAL ST-AMOUR.. « An Empirical Analysis of U.S. Aggregate Portfolio Allocations », 33 pages.

IEA-05-03 MARTIN BOILEAu ET MiCHEL nORMANDin. « Closing International Real Business Cycle Models with Restricted Financial Markets », 36 pages.

IEA-05-04 GEORGES DIONNE ET BENOIT DOSTIE. «New Evidence on the Determinants of Absenteeism Using Linked Employer-Employee Data », 35 pages.

IEA-05-05 MAURICE N. MARCHON. «Perspectives économiques canadiennes dans un contexte international », 27 pages.

IEA-05-06 RAYNAULD, JACQUES. «L'efficacité de l'apprentissage en ligne: le cas d'un cours d’économie à HEC Montréal », 10 pages

IEA-05-07 MICHEL NORMANDIN ET BRUNO POWO FOSSO. «Global versus Country-Specific Shocks and International Business Cycles», 44 pages.

IEA-05-08 RAYNAULD, JACQUES. « Le programme Virtuose : les ordinateurs portatifs et l'intégration des TIC à HEC Montréal - 1996-2001 », 88 pages 
IEA-06-01 DOSTIE, BENOIT ET LÉGER PIERRE THOMAS. « Self-selection in migration and returns to unobservable skills », 88 pages

IEA-06-02 JÉRÉMY LAURENT-LUCCHETTI AND ANDREW LEACH. «Induced innovation in a decentralized model of climate change », 34 pages. 